\title{
Third-generation inhibitors targeting EGFR T790M mutation in advanced non-small cell lung cancer
}

\author{
Shuhang Wang ${ }^{1}$, Shundong Cang ${ }^{2}$ and Delong $\mathrm{Liu}^{3,4^{*}}$
}

\begin{abstract}
The tyrosine kinase inhibitors (TKI) against epidermal growth factor receptor (EGFR) are widely used in patients with non-small cell lung cancer (NSCLC). However, EGFR T790M mutation leads to resistance to most clinically available EGFR TKIs. Third-generation EGFR TKIs against the T790M mutation have been in active clinical development. These agents include osimertinib, rociletinib, HM61713, ASP8273, EGF816, and PF-06747775. Osimertinib and rociletinib have shown clinical efficacy in phase I/II trials in patients who had acquired resistance to first- or second-generation TKIs. Osimertinib (AZD9291, TAGRISSO) was recently approved by FDA for metastatic EGFR T790M mutation-positive NSCLC. HM61713, ASP8237, EGF816, and PF-06747775 are still in early clinical development. This article reviews the emerging data regarding third-generation agents against EGFR T790M mutation in the treatment of patients with advanced NSCLC.
\end{abstract}

\section{Background}

Non-small cell lung cancer (NSCLC) accounts for approximately $85 \%$ of all lung cancers. The 5 -year survival rate in advanced NSCLC patients is less than $5 \%$. The activating mutations of epidermal growth factor receptor (EGFR) occur in approximately $10-15 \%$ of NSCLC cases in Caucasian patients and approximately 30-40\% in East Asian patients [1, 2]. The first- and secondgeneration EGFR tyrosine kinase inhibitors (TKI), erlotinib, gefitinib, and afatinib, have been widely used for these advanced NSCLC patients [3-5]. However, acquired resistance to these inhibitors frequently develops after a median of 9 to 13 months [5-11]. The common acquired EGFR mutations with clinical implications are exon 19 deletions (del19), L858R mutation, and the T790M mutation (Fig. 1) [2]. Cell lines harboring these mutations have been used for screening novel agents targeting these mutations [12]. The EGFR T790M mutation was present in approximately 50 to $60 \%$ of resistant cases [13, 14]. The median survival is less than 2 years after the emergence of T790M

\footnotetext{
* Correspondence: delong_liu@nymc.edu

${ }^{3}$ Department of Oncology, Henan Cancer Hospital, Zhengzhou University, Zhengzhou, China

${ }^{4}$ Henan Cancer Hospital, Zhengzhou University, Zhengzhou, China Full list of author information is available at the end of the article
}

mutation [13]. Recently, the third-generation EGFR inhibitors, AZD9291 (osimertinib, mereletinib), CO-1686 (rociletinib), HM61713 (BI 1482694), ASP8273, EGF816, and PF-06747775, have emerged as potential therapeutics to block the growth of EGFR T790M-positive tumors [15-17]. More importantly, unlike the first- and secondgeneration EGFR TKIs, the third-generation TKIs have a significantly increased potency for EGFR mutants than for wild-type EGFR.

\section{AZD9291 (osimertinib, mereletinib, tagrisso)}

AZD9291 is structurally different from the first- and second-generation EGFR TKIs. This compound is an irreversible mutant-selective EGFR TKI (exon 19 deletion EGFR $\mathrm{IC}_{50}=12.92 \mathrm{nM}$, L858R/T790M EGFR $\mathrm{IC}_{50}=11.44 \mathrm{nM}$, wild-type EGFR $\mathrm{IC}_{50}=493.8 \mathrm{nM}$ ) [15]. It is the only approved EGFR TKI currently indicated for patients with metastatic EGFR T790M mutation-positive NSCLC [18].

A phase I dose escalation study of AZD9291 (AURA) was done in patients with advanced EGFR-mutated NSCLC who had disease progression from the firstgeneration of EGFR TKI treatment. Patients received doses ranging from 20 to $240 \mathrm{mg} /$ day. These cohorts were not preselected according to T790M status. Five 


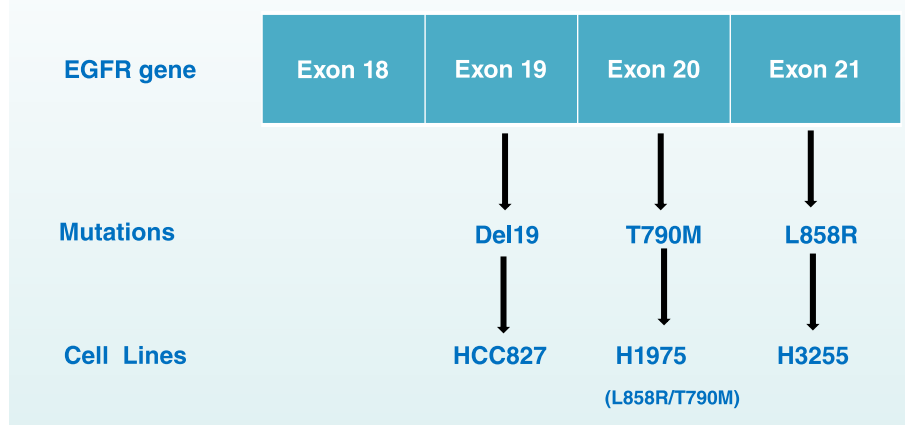

Fig. 1 Common mutations of the epidermal growth factor receptor (EGFR) that are targets for tyrosine kinase inhibitors. Exons 18 to 21 of EGFR gene are common sites for mutations. The most common mutations that are targets of EGFR TKls are shown. As an example, three mutationharboring lung cancer cell lines commonly used to characterize EGFR TKls are also shown. Del19: exon 19 deletion

expansion cohorts were stratified according to $T 790 M$ status (T790M-positive or -negative). Thirty-one patients were enrolled in the escalation cohort and 222 additional patients in the five expansion cohorts. The objective response rate (ORR) was $51 \%$ in the whole population (95\% CI 45-58 \%). Among 127 evaluable patients with EGFR T790M mutation, ORR was $67 \%$ (95 \% CI 52$70 \%)$. The response rates were similarly high across the five tested dose levels. For patients without EGFR T790M, the ORR was $21 \%$ (95 \% CI 12-34 \%) [19]. The median progression-free survival (PFS) was longer in EGFR T790M-positive patients (9.6 months; 95 \% CI 8.3 to not reached) than that in EGFR T790M-negative patients (2.8 months; $95 \%$ CI 2.1-4.3). The most common adverse effects (AE) were rash, diarrhea, nausea, and poor appetite. There were no dose-limiting toxicities (DLTs) at any dose level. Maximum tolerated dose (MTD) was not reached. At higher dose levels of 160 and $240 \mathrm{mg}$, an increase in the incidence and severity of adverse events (rash, dry skin, and diarrhea, etc.) was observed. This was thought to be associated with inhibition of non-mutant EGFR. Therefore, $80 \mathrm{mg}$ daily was recommended to be used for further clinical trials [19]. This study also suggested that EGFR T790M is not only a prognostic but also a predictive biomarker.

AZD9291 has been examined in the first-line treatment in an expansion cohort from AURA trial, doses of 80 or $160 \mathrm{mg} /$ day were administered to 60 treatmentnaïve patients with EGFR-mutated advanced NSCLC at the time of report [20]. The median age of the patients was 63.5 , stable brain metastasis was allowed. EGFR mutation subtypes included EGFR exon 19 deletion (37 \%), EGFR exon 21 L858R (40\%), other EGFR sensitizing mutations ( $3 \%$ ), and T790M in $8 \%$ of patients. ORR at the cutoff date was $70 \%$ (95\% CI 57-81). A third of the patients had grade $\geq 3$ adverse events, mainly including skin rash and diarrhea. These results appeared to be promising but clearly preliminary.

An ongoing first-line phase III trial is comparing the efficacy and safety of AZD9291 (80 mg/day) in combination with gefitinib or erlotinib in patients with common EGFR mutations. The primary end point is PFS, and the secondary end points include assessment of PFS by pretreatment T790M mutation status and by EGFR mutation subtype (exon 19 deletion or L858R) detected in circulating tumor DNA. Patients were allowed to cross over to AZD9291 after disease progression in the control arm (Table 1).

Using EGFR mutant cell lines, investigators discovered additional resistance mechanisms, such as NRAS and KRAS mutations and overexpression. A combination of AZD9291 with the MEK inhibitor, selumetinib, was shown to cause regression of AZD9291-resistant tumors in an EGFRm/T790M transgenic model [21]. Multiple ongoing trials of AZD9291 in combination with other novel agents are listed in Table 1. These agents include selumetinib (MEK inhibitor), necitumumab (EGFR antibody), navitoclax (inhibitor of Bcl-xL, Bcl-2, and $\mathrm{Bcl}-\mathrm{w}$ ) [22], and AZD6094 (MET inhibitor). 
Table 1 Ongoing clinical trials of osimertinib (AZD9291, TAGRISSO)

\begin{tabular}{lll}
\hline Phase & Study population & NCT no. \\
\hline Phase Ib & EGFR mutated advanced NSCLC progressed following therapy with an EGFR TKI & 02143466 \\
Phase I & EGFR mutated advanced NSCLC progressed following therapy with an EGFR TKI and standard therapy & 02157883 \\
Phase I & EGFR mutated advanced NSCLC progressed following therapy with an EGFR TKI & 02317016 \\
Phase III (ADAURA) & EGFR mutated stage IB-IIIA NSCLC following complete resection with or without adjuvant chemotherapy & 02511106 \\
Phase I & EGFR mutated advanced NSCLC progressed following therapy with an EGFR TKI & 02197234 \\
Phase III & EGFR mutated advanced NSCLC & 02296125 \\
Phase III & EGFR T790M mutation-positive NSCLC progressed following therapy with an EGFR TKI & 02474355 \\
Phase III & EGFR T790M mutation-positive NSCLC progressed following therapy with an EGFR TKI & 02151981 \\
Phase I & EGFR mutated advanced NSCLC progressed following therapy with an EGFR TKI & 02503722 \\
Phase I & EGFR mutated advanced NSCLC progressed following therapy with an EGFR TKI & 02496663 \\
Phase I/II & EGFR mutated advanced NSCLC progressed following therapy with an EGFR TKI & 01802632 \\
Phase I & EGFR mutated advanced NSCLC & 02228369 \\
Phase II & EGFR T790M mutation-positive NSCLC progressed following therapy with an EGFR TKI & 02094261 \\
Phase II & EGFR T790M mutation-positive NSCLC progressed following therapy with an EGFR TKI & 02442349 \\
Phase Ib & EGFR mutated advanced NSCLC progressed following therapy with an EGFR TKI & 02520778 \\
Phase IIla & Stage IIIB-IV locally advanced or metastatic NSCLC & 02179671 \\
Phase I & Chinese patients with EGFR mutated advanced NSCLC progressed following therapy with an EGFR TKI \\
Phase II & EGFR mutated advanced NSCLC progressed following therapy with an EGFR TKI & 02529995 \\
\hline
\end{tabular}

EGFR: epidermal growth factor receptor, NSCLC: non-small cell lung cancer, TKI: tyrosine kinase inhibitor

\section{Rociletinib (CO-1686)}

Rociletinib is another novel, oral, irreversible mutantselective inhibitor of commonly mutated forms of EGFR (exon 19 deletion, L858R, and T790M). Preclinical studies have shown that rociletinib has minimal activity against wild-type EGFR [16]. In xenograft and transgenic models of NSCLC with EGFR mutations including T790M, rociletinib resulted in durable tumor shrinkage [16].

A phase I/II study of rociletinib was done in patients with EGFR-mutated NSCLC with acquired resistance to first- or second-generation EGFR inhibitors [23]. In the phase II part of the study, patients with NSCLC positive for EGFR T790M received rociletinib at doses of 500, 625 , or $750 \mathrm{mg}$ twice daily. At the time of report, 130 patients were enrolled. MTD was not identified. One common DLT was hyperglycemia. Among the 46 patients with T790M-positive disease who could be evaluated, the ORR was $59 \%$ (95\% CI 45 to 73 ). For the 17 patients with T790M-negative disease, the ORR was $29 \%$ (95\% CI 8 to 51). Therefore, rociletinib was active in NSCLC patients with EGFR T790M mutation.

The confirmatory phase II trial of second-line rociletinib (625 mg twice a day) for advanced EGFR-mutated NSCLC that progressed after previous EGFR TKI therapy is ongoing (TIGER-2; NCT02147990). A randomized phase II study of first-line rociletinib versus erlotinib monotherapy for EGFR-mutated advanced NSCLC already started recruiting. The phase III trial, TIGER-3, is another open-label, multicenter, randomized study of rociletinib monotherapy versus single-agent cytotoxic chemotherapy in NSCLC patients with mutant EGFR after failure of at least one previous EGFR TKI and platinum-doublet chemotherapy. The ongoing trials of rociletinib are summarized in Table 2.

\section{HM61713 (BI 1482694)}

HM61713 is an irreversible kinase inhibitor and covalently binds to a cysteine residue near the kinase domain of mutant EGFR. HM61713 has a half-life of over $24 \mathrm{~h}$ for EGFR inhibition [24]. HM61713 caused potent inhibition in cell lines H1975 (L858R and T790M) and HCC827 (exon 19 deletion) (Fig. 1). HM61713 has a low

Table 2 Ongoing clinical trials of rociletinib (CO-1686)

\begin{tabular}{lll}
\hline Phase & Study population & NCT no. \\
\hline Phase I/II & EGFR mutated advanced NSCLC & 02580708 \\
Phase I/II & EGFR mutated advanced NSCLC & 02630186 \\
Phase II/III (TIGER-1) & $\begin{array}{l}\text { Untreated EGFR mutated advanced } \\
\text { NSCLC }\end{array}$ & 02186301 \\
Phase II (TIGER-2) & EGFR mutated NSCLC & 02147990 \\
Phase III (TIGER-3) & $\begin{array}{l}\text { EGFR mutated advanced NSCLC after } \\
\text { failure of } \geq 1 \text { previous EGFR TKI and } \\
\text { platinum-doublet chemotherapy }\end{array}$ & \\
& & \\
\hline
\end{tabular}

EGFR: epidermal growth factor receptor, NSCLC: non-small cell lung cancer, TKI: tyrosine kinase inhibitor 
potency for NSCLC cell line H358 harboring wild-type EGFR $\left(\mathrm{GI}_{50}\right.$ of $\left.2225 \mathrm{nM}\right)$. In the in vivo studies of xenograft models with grafts of H1975 and HCC827, HM61713 was active against the tumors without showing any side effects [24].

In the ongoing phase I/II study of HM61713 in patients with advanced NSCLC who had failed previous EGFR TKIs (NCT01588145), EGFR mutation-positive patients received doses ranging from 75 to $1200 \mathrm{mg} /$ day [17]. In the phase II expansion part of the study, $800 \mathrm{mg}$ QD was the dose given to patients with centrally confirmed T790M-positive NSCLC. In the latest update, 173 patients were enrolled, including 55 in the phase I and 118 in the phase II cohorts. Eight hundred milligrams once daily was the MTD. DLTs mainly involved GI symptoms and elevation of aspartate aminotransferase, alanine aminotransferase, amylase, and lipase. The ORR was $58.8 \%$ in the 34 patients who received HM61713 with a dose more than $650 \mathrm{mg}$. In addition, ten patients had unconfirmed partial responses, and 13 achieved disease stabilization [17]. Therefore, HM61713 represents another promising agent for patients with T790Mpositive NSCLC.

\section{ASP8273}

ASP8273 is another small molecule, irreversible TKI inhibitor that inhibits the kinase activity of EGFR mutations including $\mathrm{T} 790 \mathrm{M}$, with limited activity against EGFR wild-type (WT) NSCLC. In the in vitro enzymatic and cell-based assays, ASP8273 were evaluated against EGFR mutants (L858R, exon 19 deletion, L858R/T790M, and del19/T790M) and WT EGFR [25]. ASP8273 was found by mass spectrometry to covalently bind to a mutant EGFR (L858R/T790M) via cysteine residue 797 in the kinase domain of EGFR with long-lasting inhibition of EGFR phosphorylation for $24 \mathrm{~h}$. In the NSCLC cell lines harboring the above EGFR mutations, ASP8273 had $\mathrm{IC}_{50}$ values of 8-33 nM toward EGFR mutants, more potently than that of WT EGFR $\left(\mathrm{IC}_{50}\right.$ value of $230 \mathrm{nM}$ ). In mouse xenograft models, ASP8273 induced complete regression of the tumors after 14 days of treatment [25]. ASP8273 was further shown to suppress the signaling pathway through ERK and Akt. ASP8273 even showed activity in mutant EGFR cell line which is resistant to other EGFR TKIs including AZD9291 and CO-1686 [26]. Therefore, ASP8273 represents a unique agent active in NSCLC with EGFR T790M mutation.

ASP8273 was evaluated in an open-label phase I/II study for safety and efficacy [27]. As of late 2014, 30 Japanese patients were enrolled in the phase I cohorts across seven dose levels $(25-600 \mathrm{mg})$, and 15 patients were enrolled in the expansion cohorts across four dose levels (100-400 mg). EGFR T790M mutation
Table 3 Ongoing clinical trials of ASP8273

\begin{tabular}{lll}
\hline Phase & Study population & NCT no. \\
\hline Phase I & $\begin{array}{l}\text { NSCLC patients who have EGFR mutations } \\
\text { and received prior treatment with EGFR TKI }\end{array}$ & 02113813 \\
Phase I/II & $\begin{array}{l}\text { NSCLC with EGFR mutation and had } \\
\text { progressive disease after previous treatment } \\
\text { with EGFR TKIs }\end{array}$ & 02192697 \\
Phase II & $\begin{array}{l}\text { NSCLC with EGFR mutation and TKI naïve } \\
\text { patients }\end{array}$ & 02500927 \\
Phase III & Stage IIIB/IV NSCLC with EGFR mutations & 02588261
\end{tabular}

EGFR: epidermal growth factor receptor, NSCLC: non-small cell lung cancer, TKI: tyrosine kinase inhibitor

was positive in $49 \%$. There were $13 \%$ negative for T790M and $38 \%$ unknown. The most common AEs were GI toxicity and thrombocytopenia (31 \%). DLTs were reported at higher dose levels (400-600 mg). MTD was established as $400 \mathrm{mg}$. PR was achieved in $50 \%(18 / 36)$ of all evaluable patients and $80 \%(12 / 15)$ in those with T790M. From this study, $300 \mathrm{mg}$ once daily was chosen as the recommended phase II dose (RP2D) [27].

In a separate report of a phase I/II study with cutoff date of January 2015, 24 patients were enrolled across six dose escalation cohorts (25-400 mg once daily) and 11 patients were enrolled in two expansion cohorts (100-200 mg once daily) [28]. All patients had failed prior erlotinib treatment. The most common treatmentrelated AEs were mild gastrointestinal toxicities. DLTs included hyponatremia and anorexia (one case each). The ORR among the evaluable patients was $28 \%(7 / 25)$ at the cutoff date. In patients with T790M mutation, the ORR was $25 \%$ (3/12). The MTD was anticipated to be $400 \mathrm{mg}$ and the RP2D to be $300 \mathrm{mg}$. More ongoing studies are listed in Table 3.

\section{EGF816}

EGF816 is another third-generation covalent EGFR inhibitor that has potent inhibitory activity against activating (L858R, del19) and resistant T790M mutants with low $\mathrm{IC}_{50}$ in various cellular assays [12]. In mouse xenograft models, EGF816 was better than earlier generation EGFR inhibitors. EGF816 target profiles suggest that it represents an alternative and better therapy option against T790M mutations [12, 29-31].

Table 4 Ongoing clinical trials of EGF816

\begin{tabular}{|c|c|c|}
\hline Phase & Study population & NCT no. \\
\hline Phase I/II & $\begin{array}{l}\text { Patients with EGFR mutated solid } \\
\text { malignancies }\end{array}$ & 02108964 \\
\hline Phase $\mid \mathrm{b} / \|$ & Patients with EGFR mutated NSCLC & 02335944 \\
\hline Phase II & $\begin{array}{l}\text { Patients with EGFR mutated and } \\
\text { cMET-positive NSCLC }\end{array}$ & 02323126 \\
\hline
\end{tabular}

EGFR: epidermal growth factor receptor, NSCLC: non-small cell lung cancer, TKl: tyrosine kinase inhibitor 
A phase I multicenter, dose escalation study of EGF816 enrolled NSCLC patients with confirmed T790M status. The starting dose was $75 \mathrm{mg}$ daily. The doses were escalated according to an adaptive Bayesian logistic regression model. At the cutoff date of 26 January 2015, 57 patients were treated across six cohorts $(75,150,225,300$, and $350 \mathrm{mg}$ for capsules; $225 \mathrm{mg}$ for tablets). Diarrhea, stomatitis, rash, and pruritus were the most common AEs. ORR was $54.5 \%$ in 22 evaluable patients. The ongoing study is to determine the MTD and RP2D [32]. More ongoing studies are listed in Table 4.

\section{PF-06747775}

PF-06747775 is another small molecule inhibitor of EGFR T790M. This molecule is being studied in phase I/II clinical trial (NCT02349633) in advanced NSCLC patients with EGFR mutations (del 19 or L858R \pm T790M). The agent will be administered as continuous daily dosing in 21-day cycles. The starting dose of PF-06747775 will be $25 \mathrm{mg}$ PO daily.

\section{Resistance to third-generation EGFR inhibitors}

New mutations are emerging that mediate resistance to third-generation EGFR TKIs [33-37]. Among these, C797S mutation was found to be the most common mechanism responsible for resistance to AZD9291 $[33,35,36]$. C797S was also reported in one case that led to resistance to HM61713 [34]. The C797S mutation was reported to arise after approximately $6-17$ months of treatment in patients with T790M mutations [33-36]. Additional mutations and mechanisms of resistance to EGFR TKIs clearly exist since resistance to AZD9291 was reported in patients who became negative for T790M mutation and had no C797S mutation [35].

\section{Conclusions}

Clinical trials are being done on the third-generation EGFR TKIs, osimertinib, rociletinib, HM61713, ASP8273, EGF816, and PF-06747775 that are effective for T790M EGFR mutants. Osimertinib (AZD9291, TAGRISSO) was recently approved by FDA for metastatic EGFR T790M mutation-positive NSCLC. The other five inhibitors are still in clinical development. Novel agents are needed to conquer the C797S tertiary EGFR mutation. Since ALK inhibitors and immune check point blockers are also widely used for treatment of NSCLC [8, 38-46], combination and sequential therapies with these agents may improve outcome in patients with advanced NSCLC.

\section{Competing interests}

The authors declare that they have no competing interests.

\section{Authors' contributions}

DL designed the study. SW and DL drafted the manuscript. CS and DL designed and finalized the figures. All authors read and approved final manuscript.

\section{Acknowledgements}

This project was partly supported by the National Natural Science Foundation of China (Grant No. 81101726).

\section{Author details}

${ }^{1}$ The Key Laboratory of Carcinogenesis and Translational Research (Ministry of Education), Peking University Cancer Hospital, Beijing, China. ${ }^{2}$ Department of Oncology, People's Hospital of Henan Province, Zhengzhou University, Zhengzhou, China. ${ }^{3}$ Department of Oncology, Henan Cancer Hospital, Zhengzhou University, Zhengzhou, China. ${ }^{4}$ Henan Cancer Hospital,

Zhengzhou University, Zhengzhou, China.

Received: 10 March 2016 Accepted: 6 April 2016

Published online: 12 April 2016

References

1. Pao W, Chmielecki J. Rational, biologically based treatment of EGFR-mutant non-small-cell lung cancer. Nat Rev Cancer. 2010;10(11):760-74.

2. Sharma SV, Bell DW, Settleman J, Haber DA. Epidermal growth factor receptor mutations in lung cancer. Nat Rev Cancer. 2007;7(3):169-81.

3. Cataldo VD, Gibbons DL, Perez-Soler R, Quintas-Cardama A. Treatment of non-small-cell lung cancer with erlotinib or gefitinib. N Engl J Med. 2011;364(10):947-55.

4. Zhong W, Yang X, Yan H, Zhang X, Su J, Chen Z, Liao R, Nie Q, Dong S, Zhou Q, Yang J, Tu H, Wu Y-L. Phase II study of biomarker-guided neoadjuvant treatment strategy for IIIA-N2 non-small cell lung cancer based on epidermal growth factor receptor mutation status. J Hematol Oncol. 2015;8(1):54.

5. Chi A, Remick S, Tse W. EGFR inhibition in non-small cell lung cancer: current evidence and future directions. Biomark Res. 2013;1(1):2.

6. Mok TS, Wu YL, Thongprasert S, Yang CH, Chu DT, Saijo N, Sunpaweravong $P$, Han B, Margono B, Ichinose $Y$, Nishiwaki Y, Ohe Y, Yang JJ, Chewaskulyong B, Jiang $H$, Duffield EL, Watkins CL, Armour AA, Fukuoka M. Gefitinib or carboplatin-paclitaxel in pulmonary adenocarcinoma. N Engl Med. 2009:361(10):947-57.

7. Rosell R, Carcereny E, Gervais R, Vergnenegre A, Massuti B, Felip E, Palmero R, Garcia-Gomez R, Pallares C, Sanchez JM, Porta R, Cobo M, Garrido P, Longo F, Moran T, Insa A, De Marinis F, Corre R, Bover I, Illiano A, Dansin E, de Castro J, Milella M, Reguart N, Altavilla G, Jimenez U, Provencio M, Moreno MA, Terrasa J, Munoz-Langa J, et al. Erlotinib versus standard chemotherapy as first-line treatment for European patients with advanced EGFR mutation-positive non-small-cell lung cancer (EURTAC): a multicentre, open-label, randomised phase 3 trial. Lancet Oncol. 2012;13(3):239-46.

8. Sequist LV, Yang JC, Yamamoto N, O'Byrne K, Hirsh V, Mok T, Geater SL, Orlov S, Tsai CM, Boyer M, Su WC, Bennouna J, Kato T, Gorbunova V, Lee KH, Shah R, Massey D, Zazulina V, Shahidi M, Schuler M. Phase III study of afatinib or cisplatin plus pemetrexed in patients with metastatic lung adenocarcinoma with EGFR mutations. J Clin Oncol. 2013;31(27):3327-34.

9. Niu F-Y, Wu Y-L. Novel agents and strategies for overcoming EGFR TKIs resistance. Exp Hematol Oncol. 2014;3(1):2.

10. Sun W, Yuan X, Tian Y, Wu H, Xu H, Hu G, Wu K. Non-invasive approaches to monitor EGFR-TKI treatment in non-small-cell lung cancer. J Hematol Oncol. 2015;8(1):95.

11. Lee CK, Wu Y-L, Ding PN, Lord SJ, Inoue A, Zhou C, Mitsudomi T, Rosell R, Pavlakis N, Links M, Gebski V, Gralla RJ, Yang JC-H. Impact of specific epidermal growth factor receptor (EGFR) mutations and clinical characteristics on outcomes after treatment with EGFR tyrosine kinase inhibitors versus chemotherapy in EGFR-mutant lung cancer: a metaanalysis. J Clin Oncol. 2015;33(17):1958-65.

12. Jia Y, Juarez J, Li J, Manuia M, Niederst MJ, Tompkins C, Timple N, Vaillancourt M-T, Pferdekamper AC, Lockerman EL, Li C, Anderson J, Costa C, Liao D, Murphy E, DiDonato M, Bursulaya B, Lelais G, Barretina J, McNeill M, Epple R, Marsilje TH, Pathan N, Engelman JA, Michellys P-Y, McNamara P, Harris J, Bender S, Kasibhatla S. EGF816 exerts anticancer effects in non-small cell lung cancer by irreversibly and selectively targeting primary and acquired activating mutations in the EGF receptor. Cancer Res. 2016;76: 1591-602. Doi: 10.1158/0008-5472.CAN-1115-2581.

13. Yu HA, Arcila ME, Rekhtman N, Sima CS, Zakowski MF, Pao W, Kris MG, Miller VA, Ladanyi M, Riely GJ. Analysis of tumor specimens at the time of acquired resistance to EGFR-TKI therapy in 155 patients with EGFRmutant lung cancers. Clin Cancer Res. 2013;19(8):2240-7. 
14. Sequist LV, Waltman BA, Dias-Santagata D, Digumarthy $S$, Turke AB, Fidias $P$, Bergethon K, Shaw AT, Gettinger S, Cosper AK, Akhavanfard S, Heist RS, Temel J, Christensen JG, Wain JC, Lynch TJ, Vernovsky K, Mark EJ, Lanuti M, lafrate AJ, Mino-Kenudson M, Engelman JA. Genotypic and histological evolution of lung cancers acquiring resistance to EGFR inhibitors. Sci Transl Med. 2011;3(75):75ra26.

15. Cross DA, Ashton SE, Ghiorghiu S, Eberlein C, Nebhan CA, Spitzler PJ, Orme JP, Finlay MR, Ward RA, Mellor MJ, Hughes G, Rahi A, Jacobs VN, Red Brewer M, Ichihara E, Sun J, Jin H, Ballard P, Al-Kadhimi K, Rowlinson R, Klinowska T, Richmond GH, Cantarini M, Kim DW, Ranson MR, Pao W. AZD9291, an irreversible EGFR TKI, overcomes T790M-mediated resistance to EGFR inhibitors in lung cancer. Cancer Discov. 2014;4(9):1046-61.

16. Walter AO, Sjin RT, Haringsma HJ, Ohashi K, Sun J, Lee K, Dubrovskiy A, Labenski M, Zhu Z, Wang Z, Sheets M, St Martin T, Karp R, van Kalken D, Chaturvedi P, Niu D, Nacht M, Petter RC, Westlin W, Lin K, Jaw-Tsai S, Raponi M, Van Dyke T, Etter J, Weaver Z, Pao W, Singh J, Simmons AD, Harding TC, Allen A. Discovery of a mutant-selective covalent inhibitor of EGFR that overcomes T790M-mediated resistance in NSCLC. Cancer Discov. 2013;3(12):1404-15.

17. Park K, Lee J-S, Lee KH, Kim J-H, Min YJ, Cho JY, Han J-Y, Kim B-S, Kim J-S, Lee DH, Kang JH, Cho EK, Jang I-J, Jung J, Kim H-Y, Sin HJ, Son J, Woo JS, Kim D-W. Updated safety and efficacy results from phase I/II study of HM61713 in patients (pts) with EGFR mutation positive non-small cell lung cancer (NSCLC) who failed previous EGFR-tyrosine kinase inhibitor (TKI). ASCO Meet Abstr. 2015;33(15):8084.

18. Ward RA, Anderton MJ, Ashton S, Bethel PA, Box M, Butterworth S, Colclough N, Chorley CG, Chuaqui C, Cross DA, Dakin LA, Debreczeni JE, Eberlein C, Finlay MR, Hill GB, Grist M, Klinowska TC, Lane C, Martin S, Orme JP, Smith P, Wang F, Waring MJ. Structure- and reactivity-based development of covalent inhibitors of the activating and gatekeeper mutant forms of the epidermal growth factor receptor (EGFR). J Med Chem. 2013;56(17):7025-48.

19. Janne PA, Yang JC, Kim DW, Planchard D, Ohe Y, Ramalingam SS, Ahn MJ, Kim SW, Su WC, Horn L, Haggstrom D, Felip E, Kim JH, Frewer P, Cantarini M, Brown KH, Dickinson PA, Ghiorghiu S, Ranson M. AZD9291 in EGFR inhibitor-resistant non-small-cell lung cancer. N Engl J Med. 2015;372(18):1689-99.

20. Ramalingam SS, Yang J, Lee C, Kurata T, Kim D-W, John T, Nogami N, Ohe Y, Rukazenkov Y, Frewer P, Cantarini M, Ghiorghiu S, Jänne PA. MINI 16.07: AZD9291 in treatment-naïve EGFRm advanced NSCLC: AURA first-Line cohort. J Thoracic Oncol. 2015;10(9_suppl 2):S319.

21. Eberlein CA, Stetson D, Markovets AA, Al-Kadhimi KJ, Lai Z, Fisher PR, Meador CB, Spitzler P, Ichihara E, Ross SJ, Ahdesmaki MJ, Ahmed A, Ratcliffe LE, O'Brien EL, Barnes CH, Brown H, Smith PD, Dry JR, Beran G, Thress KS, Dougherty B, Pao W, Cross DA. Acquired resistance to the mutant-selective EGFR inhibitor AZD9291 is associated with increased dependence on RAS signaling in preclinical models. Cancer Res. 2015;75(12):2489-500.

22. Cang S, Iragavarapu C, Savooji J, Song Y, Liu D. ABT-199 (venetoclax) and BCL-2 inhibitors in clinical development. J Hematol Oncol. 2015;8(1):129.

23. Sequist LV, Soria JC, Goldman JW, Wakelee HA, Gadgeel SM, Varga A, Papadimitrakopoulou V, Solomon BJ, Oxnard GR, Dziadziuszko R, Aisner DL, Doebele RC, Galasso C, Garon EB, Heist RS, Logan J, Neal JW, Mendenhall MA Nichols S, Piotrowska Z, Wozniak AJ, Raponi M, Karlovich CA, Jaw-Tsai S, Isaacson J, Despain D, Matheny SL, Rolfe L, Allen AR, Camidge DR. Rociletinib in EGFRmutated non-small-cell lung cancer. N Engl J Med. 2015;372(18):1700-9.

24. Lee K-O, Cha MY, Kim M, Song JY, Lee J-H, Kim YH, Lee Y-M, Suh KH, Son J. Abstract LB-100: discovery of HM61713 as an orally available and mutant EGFR selective inhibitor. Cancer Res. 2014;74(19 Supplement):LB-100.

25. Sakagami H, Konagai S, Yamamoto H, Tanaka H, Matsuya T, Mori M, Koshio H, Yuri M, Hirano M, Kuromitsu S. Abstract 1728: ASP8273, a novel mutantselective irreversible EGFR inhibitor, inhibits growth of non-small cell lung cancer (NSCLC) cells with EGFR activating and T790M resistance mutations. Cancer Res. 2014;74(19 Supplement):1728.

26. Konagai $\mathrm{S}$, Sakagami $\mathrm{H}$, Yamamoto H, Tanaka H, Matsuya T, Mimasu S, Tomimoto Y, Mori M, Koshio H, Hirano M, Kuromitsu S, Takeuchi M. Abstract 2586: ASP8273 selectively inhibits mutant EGFR signal pathway and induces tumor shrinkage in EGFR mutated tumor models. Cancer Res. 2015; 75(15 Supplement):2586

27. Goto Y, Nokihara H, Murakami H, Shimizu T, Seto T, Krivoshik AP, Keating AT, Uegaki K, Takeda K, Komatsu K, Morita S, Fukuoka M, Nakagawa K. ASP8273, a mutant-selective irreversible EGFR inhibitor in patients (pts) with NSCLC harboring EGFR activating mutations: preliminary results of first-in-human phase I study in Japan. ASCO Meet Abstr. 2015;33(15_suppl):8014.
28. Yu HA, Oxnard GR, Spira Al, Horn L, Weiss J, Feng Y, West HJ, Giaccone G, Evans TL, Kelly RJ, Fleege T, Poondru S, Jie F, Aoyama K, Foley MA, Whitcomb D, Keating AT, Krivoshik AP. Phase I dose escalation study of ASP8273, a mutant-selective irreversible EGFR inhibitor, in subjects with EGFR mutation positive NSCLC. ASCO Meet Abstr. 2015;33(15_suppl):8083.

29. Jia Y, Juarez J, Manuia M, Lelais G, Kasibhatla S, Long O, McNeill M, DiDonato M, Bursulaya B, Liao D, Murphy E, Epple R, Marsilje T, Pathan N, Michellys P-Y, Bender S, Harris J. Abstract 1734: in vitro characterization of EGF816, a third-generation mutant-selective EGFR inhibitor. Cancer Res. 2014;74(19 Supplement):1734.

30. Kasibhatla S, Li J, Tompkins C, Vaillancourt M-T, Anderson J, Pferdekamper AC, Li C, Long O, McNeill M, Epple R, Liao D, Murphy E, Bender S, Jia Y, Lelais G. Abstract 1733: EGF816, a novel covalent inhibitor of mutant-selective epidermal growth factor receptor, overcomes T790M-mediated resistance in NSCLC. Cancer Res. 2014;74(19 Supplement):1733.

31. Lelais G, Epple R, Michellys P-Y, Marsilje TH, Long Y, McNeill M, Chen B, Lu W, Bursulaya B, DiDonato M, Jia Y, Kasibhatla S, Li C, Matushansky I, Bender S. Abstract 2585: discovery of a potent covalent mutantselective EGFR inhibitor-the journey from high throughput screening to EGF816. Cancer Res. 2015;75(15 Supplement):2585.

32. Tan DS-W, Seto T, Leighl NB, Riely GJ, Sequist LV, Felip E, Wolf J, Yang JC-H, Matushansky I, Yu X, Schmitz S-FH, Cui X, Kim D-W. First-in-human phase I study of EGF816, a third generation, mutant-selective EGFR tyrosine kinase inhibitor, in advanced non-small cell lung cancer (NSCLC) harboring T790M. ASCO Meet Abstr. 2015;33(15_suppl):8013.

33. Niederst MJ, Hu H, Mulvey HE, Lockerman EL, Garcia AR, Piotrowska Z, Sequist LV, Engelman JA. The allelic context of the C797S mutation acquired upon treatment with third-generation EGFR inhibitors impacts sensitivity to subsequent treatment strategies. Clin Cancer Res. 2015; 21(17):3924-33.

34. Song HN, Jung KS, Yoo KH, Cho J, Lee JY, Lim SH, Kim HS, Sun JM, Lee SH, Ahn JS, Park K, Choi YL, Park W, Ahn MJ. Acquired C797S mutation upon treatment with a T790M-specific third-generation EGFR inhibitor (HM61713) in non-small cell lung cancer. J Thorac Oncol. 2016. doi:10.1016/j.jtho. 2015.1012.1093.

35. Thress KS, Paweletz CP, Felip E, Cho BC, Stetson D, Dougherty B, Lai Z, Markovets A, Vivancos A, Kuang Y, Ercan D, Matthews SE, Cantarini M, Barrett JC, Janne PA, Oxnard GR. Acquired EGFR C797S mutation mediates resistance to AZD9291 in non-small cell lung cancer harboring EGFR T790M. Nat Med. 2015;21(6):560-2.

36. Yu HA, Tian SK, Drilon AE, Borsu L, Riely GJ, Arcila ME, Ladanyi M. Acquired resistance of EGFR-mutant lung cancer to a T790M-specific EGFR inhibitor: emergence of a third mutation (C7975) in the EGFR tyrosine kinase domain. JAMA Oncol. 2015;1(7):982-4.

37. Costa DB, Kobayashi SS. Whacking a mole-cule: clinical activity and mechanisms of resistance to third generation EGFR inhibitors in EGFR mutated lung cancers with EGFR-T790M. Transl Lung Cancer Res. 2015;4(6):809-15.

38. Sequist LV, von Pawel J, Garmey EG, Akerley WL, Brugger W, Ferrari D, Chen Y, Costa DB, Gerber DE, Orlov S, Ramlau R, Arthur S, Gorbachevsky I, Schwartz B, Schiller JH. Randomized phase II study of erlotinib plus tivantinib versus erlotinib plus placebo in previously treated non-small-cell lung cancer. J Clin Oncol. 2011;29(24):3307-15.

39. Shaw AT. Combining inhibitors of ALK and ROS1 with other agents for the treatment of non-small cell lung cancer. Clin Adv Hematol Oncol. 2015;13(5):282-4

40. Shaw AT, Gandhi L, Gadgeel S, Riely GJ, Cetnar J, West H, Camidge DR, Socinski MA, Chiappori A, Mekhail T, Chao BH, Borghaei H, Gold KA, Zeaiter A, Bordogna W, Balas B, Puig O, Henschel V, Ou SI, study i. Alectinib in ALKpositive, crizotinib-resistant, non-small-cell lung cancer: a single-group, multicentre, phase 2 trial. Lancet Oncol. 2015;17(2):234-42.

41. Wu J, Savooji J, Liu D. Second- and third-generation ALK inhibitors for non-small cell lung cancer. J Hematol Oncol. 2016;9(1):19.

42. Shaw AT, Kim DW, Mehra R, Tan DS, Felip E, Chow LQ, Camidge DR, Vansteenkiste J, Sharma S, De Pas T, Riely GJ, Solomon BJ, Wolf J, Thomas M, Schuler M, Liu G, Santoro A, Lau YY, Goldwasser M, Boral AL, Engelman JA. Ceritinib in ALK-rearranged non-small-cell lung cancer. N Engl J Med. 2014:370(13):1189-97.

43. Iragavarapu C, Mustafa M, Akinleye A, Furqan M, Mittal V, Cang S, Liu D. Novel ALK inhibitors in clinical use and development. J Hematol Oncol. 2015;8(1):17. 
44. Borghaei H, Paz-Ares L, Horn L, Spigel DR, Steins M, Ready NE, Chow LQ, Vokes EE, Felip E, Holgado E, Barlesi F, Kohlhäufl M, Arrieta O, Burgio MA, Fayette J, Lena H, Poddubskaya E, Gerber DE, Gettinger SN, Rudin CM, Rizvi N, Crinò L, Blumenschein GRJ, Antonia SJ, Dorange C, Harbison CT, Graf Finckenstein F, Brahmer JR. Nivolumab versus docetaxel in advanced nonsquamous nonsmall-cell lung cancer. N Engl J Med. 2015;373(17):1627-39.

45. Brahmer J, Reckamp KL, Baas P, Crinò L, Eberhardt WEE, Poddubskaya E, Antonia S, Pluzanski A, Vokes EE, Holgado E, Waterhouse D, Ready N, Gainor J, Arén Frontera O, Havel L, Steins M, Garassino MC, Aerts JG, Domine M, Paz-Ares L, Reck M, Baudelet C, Harbison CT, Lestini B, Spigel DR. Nivolumab versus docetaxel in advanced squamous-cell non-small-cell lung cancer. $\mathrm{N}$ Engl J Med. 2015;373(2):123-35.

46. Davar D, Socinski MA, Dacic S, Burns TF. Near complete response after single dose of nivolumab in patient with advanced heavily pre-treated KRAS mutant pulmonary adenocarcinoma. Exp Hematol Oncol. 2015;4(1):34.

Submit your next manuscript to BioMed Central and we will help you at every step:

- We accept pre-submission inquiries

- Our selector tool helps you to find the most relevant journal

- We provide round the clock customer support

- Convenient online submission

- Thorough peer review

- Inclusion in PubMed and all major indexing services

- Maximum visibility for your research

Submit your manuscript at www.biomedcentral.com/submit
Biomed Central 